\title{
Model E-Readiness untuk Pengukuran Kesiapan Pengelolaan Aduan E-Lapor DIY
}

\author{
E-Readiness Model for Measuring the Readiness of DIY E-Lapor \\ Complaint Management
}

\author{
Dwi Lestari*1, Wing Wahyu Winarno ${ }^{2}$, Mei P Kurniawan ${ }^{3}$ \\ ${ }^{1,3}$ Universitas Amikom Yogyakarta, ${ }^{2}$ STIE YKPN Yogyakarta \\ E-mail: *11wi.0707@students.amikom.ac.id, ${ }^{2}$ wingww@outlook.com, \\ ${ }^{3}$ meikurniawan@amikom.ac.id
}

\begin{abstract}
Abstrak
Pemanfaatan TIK secara efektif dan efisien telah digunakan untuk meningkatkan pelayanan publik yang diselenggarakan oleh Pemerintah. Pemerintah Daerah DIY telah mengembangkan aplikasi aduan E-Lapor sejak 2018, akan tetapi pengelolaanya aduan yang masuk belum terespon tepat waktu sesuai dengan SOP E-Lapor DIY dimana aduan yang masuk harus direspon paling lambat 5 hari kerja. Sehingga untuk mengetahui hambatan dan kendala dalam pengelolaan E-Lapor DIY diperlukan pengukuran kesiapan faktor-faktor dalam pengelolaan E-Lapor DIY. Suksesnya pengelolaan E-lapor DIY bukan hanya dipengaruhi oleh faktor infrastruktur TIK saja, akan tetapi faktor yang turut mempengaruhi tingkat kesiapan. Telah dikembangkan pada tingkat negara tertentu beberapa model e-readiness yang mengidentifikasi dari faktor-faktor perspektif makro. Sebelum melakukan pengukuran e-readiness terdapat hal yang krusial yang perlu dilakukan yaitu dengan pemilihan model e-readiness yang tepat. Penelitian ini menggunakan pendekatan studi literatur dengan membandingkan beberapa model e-readiness yang telah popular dan sudah sering diadopsi dalam penelitian di Indonesi. Penelitian ini akan menghasilkan sebuah rekomendasi model e-readiness Mutula Brakel yang paling sesuai untuk pengukuran kesiapan dalam pengelolaan aduan melalui aplikasi E-lapor DIY.
\end{abstract}

Kata Kunci-e-lapor, e-readiness, tik, mutula dan brakel

\begin{abstract}
Effective and efficient use of ICT has been used to improve public services provided by the Government. The Regional Government of DIY has developed the E-Lapor complaint application since 2018, but the management of complaints that come in yet responded on time in accordance with the E-Lapor DIY procedure where the incoming complaint must be responded to no later than 5 working days. Efforts to determine the obstacles in managing E-Lapor DIY are needed to measure the readiness of the factors in managing E-Lapor DIY. The success of E-Lapor DIY management is not only influenced by ICT infrastructure factors, but also factors that influence the level of readiness. There are several e-readiness models that have been developed by identifying factors from a macro perspective at a particular country level. The selection of the right e-readiness model is an important thing that needs to be done, before measuring ereadiness. This research will compare several popular e-readiness models and are often adopted in research in Indonesia with a literature study approach. This study produces recommendations for the Mutula Brakel e-readiness model that is suitable for measuring readiness in complaint management through the E-Lapor DIY application.
\end{abstract}

Keywords-e-lapor, e-readiness, ICT, mutula dan brakel 


\section{PENDAHULUAN}

Pemanfaatan Teknologi Informasi dan Komunikasi untuk memudahkan akvitas bagi penggunanya. Perkembangan TIK dimanfaatkan oleh pemerintah dalam pelaksanaan pelayanan publik untuk meningkatkan kualitas layanan kepada masyarakat. Salah satu tolak ukur kinerja instansi pemerintah adalah pelayanan yang berkualitas. Masyarakat memerlukan pemenuhan kebutuhan informasi agar merasa aman dan nyaman [1]. Sumber daya TIK yang dimanfaatankan secara maksimal membuka peluang Pemerintah untuk diterapkannya cara-cara baru dalam menyelenggarakan layanan publik secara transparan, efektif, efisien, dan akuntabel [2]. Hal ini juga berdampak pada layanan aduan masyarakat yang diselenggarakan oleh Pemerintah sudah melalui apalikasi yang mudah diakses oleh masyarakat dalam menyampaikan aspirasi ataupun keluhan tentanng layanan publik yang diterimanya bila tidak sesuai dengan harapan [3].

Isu-isu yang penting sekarang adalah penilaian tentang readiness pengaduan yang belum banyak diteliti secara spesifik di pemerintahan. Dalam hal ini khusus tentang readiness dalam pengelolaan E-Lapor DIY sebagai saluran masyarakat dalam menyampaikan aspirasinya terkait dengan pelayanan publik.

Penelitian sebelumnya tentang penilaian model readiness dilakukan oleh Nento (2017) yang hasil dari penelitiannya adalah rekomendasi bahwa model $e$-readiness ICT-Pura menjadi acuan dalam mengukur tingkat kesiapan smart goverment readiness di Provinsi Gorontalo [4]. Perbedaan dengan penelitian Nento (2017) adalah metodologi yang digunakan relatif sama, hanya saja objek yang digunakan berbeda, yaitu pengelolaan pengaduan E-Lapor DIY.

\subsection{Sistem Pengaduan}

Pelayanan publik menjadi salah satu dalam implementasi demokrasi yaitu dengan memberikan masyarakat kesempatan dalam menyampaikan keluhan (complaint) bilamana pelayanan yang diterimanya tidak sesuai dengan harapan [5]. Sistem pengaduan merupakan salah satu cara untuk menanggapi adanya ketidakpuasan masyarakat dalam pelayanan publik yang diterimanya. Hak akan memperoleh tanggapan atas aduan yang disampaikan masyarakat diatur dalam Pasal 18 Ayat (c) Undang-Undang Nomor 25 Tahun 2009 tentang Pelayanan Publik, yang menyebutkan bahwa masyarakat berhak mendapatkan tanggapan terhadap pengaduan yang diajukan [6]. Hal tersebut juga ditegaskan dalam Peraturan Presiden Nomor 76 Tahun 2013 tentang Pengelolan Publik [7]. Diperlukan pemahaman sikap dan perubahan kepentingan publik dalam memberikan pelayanan publik yang lebih baik [3]. Perkembangan teknologi informasi merupakan salah satu perkembangan yang terjadi didalam masyarakat hingga saat ini [8].

Menurut Bappenas [5] sistem pengaduan akan mendatangkan manfaat atau keuntungan bagi organisasi bila mana dikelola dengan baik, antara lain:

a. Organisasi dapat mengetahui akan kekurangan atau kelemahan pelayanan publik yang diselenggarakan kepada pelanggannya

b. Memperhatiakan dan responsif terhadap suara dan pilihan pelanggan sebagai alat introspeksi organisasi

c. Mempermudah dalam mencari jalan keluar untuk meningkatkan mutu pelayanan organisasi

d. Bila keluhan atau suara pelanggan segera ditangani, maka pelanggan akan merasakan kepentingan dan harapannya diperhatikan

e. Dapat meningkatkan kesetiaan dan kepercayaan setiap pelanggan pada organisasi

Kepuasan pelanggan akan meningkat dengan adanya penanganan atau komplain yang cepat dan benar.

Tahun 2018 Pemda DIY mengembangakan aplikasi aduan E-Lapor DIY, akan tetapi belum semua keluhan yang masuk direspon tepat waktu. Sesuai dengan SOP E-Lapor DIY yang dimaksud keluhan direspon tepat waktu bila keluhan yang masuk dapat direspon paling lambat 5 hari kerja [9]. Upaya yang dilakukan untuk mendorong kinerja pengelolaan E-lapor DIY agar lebih optimal, yaitu dengan mengetahui hambatan dan kendala yang ada. Hal ini dapat diketahui 
dengan mengukur tingkat kesiapan yang mempengaruhi dalam pengelolaan E-Lapor DIY, diharapkan nantinya dapat meningkatkan kualitas pelayanan Pemda DIY.

\subsection{E-Readiness}

E-readiness digunakan untuk mengukur seberapa besar organisasi dalam menerapkan teknologi informasi dan dapat memberi petunjuk yang dapat memberi petunjuk yang dapat membimbing pengambil kebijakan dalam membuat keputusan yang berkaitan dengan pengembangan teknologi informasi yang perlu dilakukan [10]. Tingkat readiness digunakan untuk memotret profil dan kepastian pemanfaatan teknologi informasi serta mengevaluasi kecukupannya dalam mencapai suatu tujuan tertentu [1]. Terdapat perbedaan pemahaman dalam memahami e-readiness bagi masing-masing orang, hal itu tergantung pada konteks dan tujuan dalam penggunaanya [4]. Maka diperlukan pengukuran kesiapan faktor-faktor yang terkait dengan pemanfaatan TIK dalam pengelolaan E-Lapor DIY. Suksesnya pengelolaan E-Lapor DIY bukan hanya dipengaruhi oleh faktor infrastruktur TIK saja, akan tetapi faktor yang turut mempengaruhi tingkat kesiapan. Dengan demikian, maka diharapakan penetapan kebiajakan TIK dalam pengelolaan E-Lapor agar dapat meningkatkan kualitas layanan publik.

Model e-readiness telah dikembangkan dengan berbagai model yang disesuaikan dengan faktor-faktor dan perspektif makro di negara tertentu. Hal krusial yang perlu dilakukan yaitu pemilihan model e-readiness yang paling tepat dan sesuai. Penelitian ini akan membandingkan beberapa jenis model $e$-readiness yang telah populer dan sering diadopsi dalam penelitian. Hasil dari penelitian ini yaitu sebuah rekomendasi model $e$-readiness yang paling sesuai dalam menilai kesiapan pengelolaan aduan melalui aplikasi E-lapor DIY. Menurut Bappenas faktor-faktor yang mempengaruhi pengelolaan layanan aduan antara lain kebijakan, sumber daya manusia dan infrastruktur [5].

\subsection{Penilaian E-Readiness}

Selama beberapa tahun terakhir, terdapat beberapa e-readiness yang dikembangkan oleh organisasi yang berbeda. Terdapat beberapa model penilaian e-readiness, sehingga tidak ada model penilain yang dijadikan acuan dalam penilaian pemanfaatan TIK. Suatu penelitian dapat menggunakan model dasar penilaian e-readiness yang telah dikembangkan oleh organisasi ataupun institusi pendidikan yang telah teruji akan model penilainnya dalam berbagai sector seperti ekonomi, ekspor impor, pendidikan dan juga pemerintahan. Beberapa Negara berkembang telah memodifkasi penilaian $e$-readiness sesuai dengan kebutuhan penelitian.

Negara ataupun organisasi telah mengembangkan e-readiness assesment models yang berbeda-beda. E-readiness assesment models dibagi dalam dua kelompok. Kelompok pertama yaitu e-readiness assesment models dengan fokus pada infrastruktur dasar atau suatu kesiapan organisasi dalam pertumbuhan bidang bisnis dan ekonomi yang disebut dengan e-economy. Sedangkan kelompok kedua yang disebut dengan $e$-society yang merupakan kelompok dengan fokus pada kemampuan masyarakat secara keseluruhan dalam mengambil manfaat dari TIK [11]. Pemilihan e-readiness assesment models tergantu pada tujuan yang akan dicapai oleh penggunanya [12]. Tabel 1 menunjukan adanya e-readiness assesment models yang berfokus pada masing-masnig bidangnya. 
Citec Journal, Vol. 7, No. 2, Juli 2020

ISSN: 2354-5771

Tabel 1. E-readiness Assesment Models

\begin{tabular}{|c|c|c|c|c|}
\hline Model & Pengembang & Fokus & Tahun & Metodelogi \\
\hline $\begin{array}{l}\text { Knowledge } \\
\text { assessment } \\
\text { methodology } \\
\end{array}$ & World Bank & E-economy & 1998 & Kualitatif \\
\hline Apec & $\begin{array}{l}\text { The Asuian Pasific Economi } \\
\text { Cooperation (APEC) Electronic } \\
\text { Commerce Steering Group }\end{array}$ & E-economy & 1999 & Kualitatif \\
\hline ICT assements & USAID & E-society & 1999 & Kualitatif \\
\hline $\begin{array}{l}\text { International survey } \\
\text { of e-commers }\end{array}$ & WITSA & E-economy & 2000 & Kualitatif \\
\hline $\begin{array}{l}\text { Information Society } \\
\text { Index }\end{array}$ & $I D C$ & E-society & $\begin{array}{l}2000- \\
2002 \\
\end{array}$ & Kualitatif \\
\hline $\begin{array}{l}\text { Teknology } \\
\text { Archievement Index }\end{array}$ & UNDP & E-society & 2001 & Kualitatif \\
\hline $\begin{array}{l}\text { ICT Development } \\
\text { Indeces }\end{array}$ & UNCTAD & E-society & 2001 & Kualitatif \\
\hline Readiness Guide & $\begin{array}{l}\text { Computer System Policy Project } \\
\text { (CSPP) }\end{array}$ & E-society & $\begin{array}{l}2002- \\
2003\end{array}$ & Kualitatif \\
\hline $\begin{array}{l}\text { Networked } \\
\text { Readiness Index }\end{array}$ & $\begin{array}{l}\text { The Center for Internasional } \\
\text { Development at Harvard and IBM } \\
\text { (CID's) }\end{array}$ & E-society & $\begin{array}{l}2002- \\
2003\end{array}$ & Kualitatif \\
\hline $\begin{array}{l}\text { E-readiness } \\
\text { Assessment }\end{array}$ & ASEAN & E-society & 2001 & Kualitatif \\
\hline $\begin{array}{l}\text { McConnell } \\
\text { International }\end{array}$ & $\begin{array}{l}\text { McConnell International prepared } \\
\text { this report in collaboration with } \\
\text { World Informatioan Technology } \\
\text { and Services alliance (WITSA) }\end{array}$ & E-economy & $\begin{array}{l}2000- \\
2002\end{array}$ & Kualitatif \\
\hline $\begin{array}{l}\text { E-Business } \\
\text { Readiness Ranking }\end{array}$ & The Economist Intelligence Unit & E-economy & 2003 & Kualitatif \\
\hline
\end{tabular}

\section{METODE PENELITIAN}

Penelitian ini menggunakan metode studi literatur dengan menghimpun informasi, datadata atau sumber yang berhubungan dengan topik yang akan diteliti. Data yang dihimpun dalam penelitian ini tentang model pengukuran e-readiness yang telah dikembangkan. Dari berbagai model pengukuran $e$-readiness tersebut kemudian dianalisis dengan mambandingkan variabel yang ada. Kesimpulan yang diperoleh merupakan sebuah model pengukuran e-readiness yang dipilih berdasarkan nilai variabel dengan jumlah tertinggi, yang selanjutnya akan digunakan dalam pengukuran kesiapan pengelolaan aduan E-Lapor DIY.

\section{HASIL DAN PEMBAHASAN}

\subsection{Perbandingan model Pengkuran E-Readiness}

Kesuksesan pengelolaan suatu sistem terletak pada kesiapan faktor-faktor yang mempengaruhi dalam pengelolaannya. Salah satu metode untuk mengukur pemanfaatan TIK dalam suatu lembaga atau organisasi adalah metode e-readiness. Society's readiness for participating in network world merupakan Pengukuran e-readiness yang dilakukan oleh Computer Systems policy Project (CSPP) pertama kalinya pada tahun 1998. Sampai sekarang terdapat beberapa model assessment tool yang telah dikembangkan oleh organisasi riset, perguruan tinggi, perusahaan, badan dan perorangan sesuai dengan orientasi yang dibutuhkan. 
Menurut Beig (2010) tidak seharusanya berasumsi bahwa penilaian yang menggunakan faktor yang sama akan menyumbangkan hasil yang sama juga akan tetapi ia berada dalam situasi lingkungan yang berbeda [13]. Perlu menjadi pertimbangan bahwa pengukuran e-readiness harus disesuaikan dengan situasi, latar belakang dan lingkungan yang akan dinilai. Permasalahan yang dihadapi dalam menilai e-readiness adalah kurang maksimalnya prosedur dalam mendukung sebuah analisis komparatif dalam standar umum. Perbandingan model-model dalam $e$-readiness dapat dilihat pada Tabel 2 .

Tabel 2. Perbandingan Model-model E-Readiness.

\begin{tabular}{|c|c|c|c|c|}
\hline Model & Jenis & Peneliti & Deskripsi & Fokus \\
\hline $\begin{array}{l}\text { Readiness } \\
\text { Guide for } \\
\text { Living in the } \\
\text { Networked } \\
\text { World } \\
\text { (1998) }\end{array}$ & $\begin{array}{l}\text { Studi kasus } \\
\text { menggunakan } \\
\text { quisoner yang } \\
\text { telah } \\
\text { disediakan }\end{array}$ & $\begin{array}{l}\text { Computer } \\
\text { Systems Policy } \\
\text { Project (CSPP) }\end{array}$ & $\begin{array}{l}\text { Mengukur kesiapan } \\
\text { masyarakat melalui } \\
\text { kuisoner } 23 \\
\text { pertanyaan } \\
\text { berdasarkan } 4 \text { tahap } \\
\text { pembangunan }\end{array}$ & $\begin{array}{l}\text { Fokus } 5 \text { kategori yaitu: } \\
\text { Infrastruktur, } \\
\text { Akses, } \\
\text { Aplikasi dan layanan, } \\
\text { Ekonomi, } \\
\text { Enabler }\end{array}$ \\
\hline $\begin{array}{l}\text { Global } \\
\text { Diffusion of } \\
\text { the Internet: } \\
\text { Case Studies } \\
\text { (1998) }\end{array}$ & $\begin{array}{l}\text { Studi kasus } \\
\text { suatu negara }\end{array}$ & $\begin{array}{l}\text { The Mosaic } \\
\text { Group }\end{array}$ & $\begin{array}{l}\text { Menggambarkan } \\
\text { peningkatan dan } \\
\text { penggunaan internet } \\
\text { dengan kobinasi } \\
\text { statistik, deskripsi } \\
\text { narasi dan } \\
\text { perbandingan }\end{array}$ & $\begin{array}{l}\text { Fokus } 6 \text { pada kategori: } \\
\text { Besarnya kegunaan; } \\
\text { Dispersi Geographic; } \\
\text { Penyerapan sektoral; } \\
\text { Infrastruktur } \\
\text { konektivitas; } \\
\text { Infrastruktur organisasi; } \\
\text { Kecanggihan } \\
\text { penggunaan. }\end{array}$ \\
\hline $\begin{array}{l}\text { E-Readiness } \\
\text { Rankings } \\
(2002)\end{array}$ & $\begin{array}{l}\text { Studi kasus } \\
\text { menggunakan } \\
\text { quisoner yang } \\
\text { telah } \\
\text { disediakan }\end{array}$ & $\begin{array}{l}\text { The Economist } \\
\text { Intelligence } \\
\text { Unit and } \\
\text { Pyramid } \\
\text { Research }\end{array}$ & $\begin{array}{l}\text { Terdapat penjelasan } \\
\text { tentang hasil dan } \\
\text { perubahan peringkat } \\
\text { terakir. Terdapat } 99 \\
\text { indikator, diantaranya } \\
70 \text { indikator } \\
\text { merupakan kategori } \\
\text { lingkungan bisnis dan } \\
\text { indikator lainnya dari } \\
5 \text { kategori. }\end{array}$ & $\begin{array}{l}\text { Fokus pada } 6 \text { kategori : } \\
\text { Konektivitas dan } \\
\text { infrastruktur teknologi } \\
\text { (25\%); } \\
\text { Lingkungan bisnis } \\
\text { (20\%); } \\
\text { Konsumen dan adopsi } \\
\text { bisnis (20\%); } \\
\text { Sosial dan infrastruktur } \\
\text { budaya (15\%); } \\
\text { Hukum dan kebijakan } \\
\text { lingkungan (15\%); } \\
\text { Mendukung e-services } \\
\text { (5\%). }\end{array}$ \\
\hline $\begin{array}{l}\text { International } \\
\text { Survey of E- } \\
\text { Commerce } \\
\text { (2002) }\end{array}$ & $\begin{array}{l}\text { Studi kasus } \\
\text { menggunakan } \\
\text { wawancara dan } \\
\text { laporan yang } \\
\text { berbasis survei }\end{array}$ & $\begin{array}{l}\text { Word } \\
\text { Information } \\
\text { Technology } \\
\text { and Services } \\
\text { Alliance }\end{array}$ & $\begin{array}{l}\text { Laporan berdasarkan } \\
\text { pada survei } \\
\text { perusahan teknologi } \\
\text { atas pengalamannya } \\
\text { menggunakan e- } \\
\text { barriers dan meminta } \\
\text { rekomendasi. } \\
\text { Laporan berisi } \\
\text { kesimpulan umum } \\
\text { serta grafik dan akun } \\
\text { narasi dari jawaban } \\
\text { survei. }\end{array}$ & $\begin{array}{l}\text { Fokus pada pengukuran } \\
\text { kesiapan pasar dunia } \\
\text { untuk e-commerce } \\
\text { dengan faktor : } \\
\text { Ekonomi ; } \\
\text { Lingkungan regulatory. }\end{array}$ \\
\hline
\end{tabular}


Citec Journal, Vol. 7, No. 2, Juli 2020

ISSN: 2354-5771

\begin{tabular}{|c|c|c|c|c|}
\hline $\begin{array}{l}\text { Global } \\
\text { Teknology } \\
\text { Index (2002) }\end{array}$ & $\begin{array}{l}\text { Studi kasus } \\
\text { dengan } \\
\text { wawancara dan } \\
\text { laporan dari } \\
\text { hasil survei }\end{array}$ & $\begin{array}{l}\text { Howard A, } \\
\text { Rubin and } \\
\text { MatricNet }\end{array}$ & $\begin{array}{l}\text { Menggunakan } \\
\text { pendekatan } \\
\text { kuantitatif dan } \\
\text { kuantitatif pada } \\
\text { teknologi serta } \\
\text { kekuatan negara } \\
\text { menggunakan } 25 \\
\text { indikator. Hasilnya } \\
\text { berupa trafik } \\
\text { rengking }\end{array}$ & $\begin{array}{l}\text { Fokus pada } 5 \text { kategori, } \\
\text { yaitu: } \\
\text { Pekerjaan; } \\
\text { Pengetahuan; } \\
\text { Globalisasi; } \\
\text { Persaingan dan } \\
\text { dinamisme ekonomi; } \\
\text { Transformasi ke } \\
\text { ekonomi digital; } \\
\text { Kapasitas inovasi } \\
\text { teknologi. }\end{array}$ \\
\hline $\begin{array}{l}\text { Readiness for } \\
\text { the Networked } \\
\text { World (2005) }\end{array}$ & $\begin{array}{l}\text { Studi kasus } \\
\text { menggunakan } \\
\text { quisoner yang } \\
\text { telah } \\
\text { disediakan }\end{array}$ & $\begin{array}{l}\text { Center } \\
\text { Internasional } \\
\text { Development } \\
\text { at Harvard } \\
\text { University }\end{array}$ & $\begin{array}{l}\text { Menilai kesiapan } \\
\text { pada masyarakat } \\
\text { dengan } 4 \text { stage } \\
\text { dengan } 19 \text { indikator } \\
\text { yang berdasarkan } \\
\text { perkiraan mandiri } \\
\text { dari pendapat } \\
\text { masyarakat }\end{array}$ & $\begin{array}{l}\text { Fokus pada } 4 \text { kategori, } \\
\text { yaitu: } \\
\text { Access learning; } \\
\text { Society; } \\
\text { Ekonomy; } \\
\text { Policy. }\end{array}$ \\
\hline
\end{tabular}

\subsection{Perbandingan Variabel Model E-Readiness}

Pengukuran e-readiness E-lapor DIY untuk mengilustrasikan tingkat kesiapan pengelolaan aduan masyarakat tentang pelayanan publik yang diselenggarakan oleh Pemerintah. Hasil dari pengukuran e-readiness dapat menjadi acuan dalam meningkatkan layanan dan pemanfaatan TIK dalam pengelolaan aduan. Sehingga dari kondisi ini diperlukan adanya acuan yang dijadikan strategi dalam mengoptimalkan pengelolaan aduan E-lapor DIY.

Menurut Bappenas [5] variabel dalam pengukuran kesiapan pengaduan antara lain:

1. Komitmen pimpinan merupakan unsur dari keinginan ataupun kemauan dari pimpinan sebuah organisasi untuk melaksanakan kebijakan yang telah disepakati untuk mengelola serta mengembangkan penyelenggaraan aduan

2. Tingkat pendidikan dapat mempengaruhi kontribusi terhadap kapasitas sumber daya manusia dalam pengelolaan pengaduan

3. Proses manajemen komplain, yang terdiri dari:

a. Standar Operasi Palayanan (SOP) merupakan sekumpulan instruksi atau perintah sebagai suatu petunjuk yang memiliki prosedur atau pemetaan yang pasti danterstandarisasi untuk malakukan manajemen komplain

b. Organisasi merupakan kelompok atau institusi yang memiliki tujuan yang sama untuk pengelola komplain

c. Sumber Daya Manusia (SDM) merupakan individu yang bekerja sebagai penggerak, pemikir dan perencana serta menjadi salah satu kunci sukses dalam manajemen komplain

d. Infrastruktur dan sarana (TIK) merupakan sarana yang memanfaatkan teknologi dalam manajemen komplain

e. Pendanaan operasional adalah segala biaya yang terkait dengan pengelolaan komplain

f. Manajemen data merupakan proses dari sumber informasi yang memastikan informasi yang akurat, mutakhir, aman dan tersedia bagi penggunanya untuk mendukung management komplain

g. Kebijakan keputusan mengenai manajemen komplai teruma pada sisi ketersediaan payung hukum yang menjadi landasan pelaksaan pengelolaan aduan

4. Implementasi menajemen komplain atau keluhan pada organisasi pemerintahan akan selalu dipengaruhi oleh fasilitas merit sistem, aspek organisasi, manajemen data, infrastruktur dan sarana, serta anggaran operasional. 
Dalam hal ini, pengukuran e-readiness aduan E-lapor DIY berfokus pada pengelolaan aduan sehingga variabel sesuai dengan Bappenas fokus ke proses manajemen komplainnya. Berdasarkan dari pertimbangan-pertimbangan tersebut, selanjutnya dilakukan perbandingan terhadap model $e$-readiness yang nantinya akan digunakan dalam pengukuran penilaian kesiapan pengelolaan E-lapor DIY yang berdasarkan pada variabel dari Bappenas [5]. Perbandingan tersebut dapat dilihat pada Tabel 3.

Tabel 3. Perbandingan Variabel Model E-Readiness.

\begin{tabular}{lllllllll}
\hline \multirow{2}{*}{ Model } & \multicolumn{7}{c}{ Dimensi Pendekatan } & \multirow{2}{*}{ Jumlah } \\
\cline { 2 - 8 } & A & B & C & D & E & F & G & \\
\hline $\begin{array}{l}\text { Readiness Guide for Living in the } \\
\text { Networked World }\end{array}$ & & & 1 & 1 & 1 & & 3 \\
\hline $\begin{array}{l}\text { Global Diffusion of the Internet: Case } \\
\text { Studies }\end{array}$ & 1 & 1 & 1 & & 1 & & 4 \\
\hline E-Readiness Rankings & & & 1 & & & 1 & 2 \\
\hline International Survey of E-Commerce & & & & 1 & & & 1 \\
\hline Global Technology Index & & & 1 & 1 & 1 & & 3 \\
\hline Readiness for the Networked World & & & 1 & 1 & & 1 & 3 \\
\hline E-Readiness Mutula dan Brakel & 1 & 1 & 1 & 1 & & 1 & 1 & 6 \\
\hline
\end{tabular}

Keterangan:

Angka "1" = suatu model mengakomodir poin-poin tersebut

A $=$ SOP

$\mathrm{B} \quad=$ Organisasi

$\mathrm{C}=\mathrm{SDM}$

$\mathrm{D} \quad=$ TIK

$\mathrm{E} \quad=$ Pendanaan

$\mathrm{F} \quad=$ Manajemen Data (Informsi)

$\mathrm{G} \quad=$ Kebijakan

Dari hasil Tabel 3 perbandingan variabel tujuh model $e$-readiness didapatkan $e$-readiness model International Survey of E-Commerce mempunyai nilai terendah yaitu 1 dengan variabel pendaanaan. Jumlah nilai tertinggi dengan enam variabel yaitu model e-readiness yang dikembangkan oleh Mutula dan Brakel dengan variabel SOP, organisasi, SDM, TIK, manajemen data (informasi) dan kebijakan. Dengan demikian model yang direkomendasikan untuk dijadikan acuan dalam pengukuran e-readiness pengelolaan aduan E-Lapor DIY adalah yang dikembangkan oleh Mutula dan Brakel.

E-readiness Mutula dan Brakel (2006) mengedepankan new e-readiness integrated model yang menekankan akses informasi dan juga mempertimbangkan berbagai segmen terkait, yaitu information readiness (kesiapan informasi), enterprise readiness (kesiapan lembaga), human resources readiess (kesiapan sumber daya manusia), ICT readiness (kesiapan infrastruktur) dan external environment readiness (kesiapan lingkungan eksternal). Tool atau segmen yang digunakan dalam e-readiness Mutula dan Brakel antara lain:

1. Enterprise readiness

Segmen ini berhubungan dengan penilaian kesiapan dari sisi enterprise, terdapat dua puluh sembilan komponen penilaian

2. Human resources readiness

Segmen ini berhubungan dengan penilaian pada sisi kesiapan sumber daya manusia, terdapat sembilan belas komponen penilaian

3. Information readiness

Segmen ini berhubungan dengan penilaian pada sisi kesiapan informasi, terdapat dua puluh satu komponen penilaian 
Citec Journal, Vol. 7, No. 2, Juli 2020

ISSN: 2354-5771

4. ICT readiness

Segmen ini berhubungan dengan penilaian pada sisi kesiapan infrastruktur TIK, terdapat dua puluh dua komponen penilaian

5. External environment readiness

Segmen ini berhubungan dengan penilaian pada sisi kesiapan lingkungan eksternal, terdapat dua puluh satu komponen penilaian.

Menurut Mutula dan Brakel bila penilaian e-readiness diterapkan pada proses sebuah evaluasi merupakan langkah awal menuju perubahan ke arah yang lebih baik dalam pelaksanaan perencanaan yang akan membawa perubahan pada kehidupan manusia secara nyata [14]. Ereadiness sangat berarti dan efektif bagi patokan perbandingan serta panduan usaha pengembangan dalam merencanakan masa depan dengan memahami kondisi terkini. Dengan demikian, e-readiness merupakan salah satu alat yang penting dalam menilai dampak TIK dengan menggantikan pendapat dan mitos yang buruk mengenai manfaat dan peran teknologi informasi dan komunikasi dalam pengembangannya [15].

\section{KESIMPULAN}

Dari pembahasan yang telah dilakukan, dapat diambil kesimpulan bahwa model $e$ readiness yang dikembangkan oleh Mutula dan Brakel merupakan model yang direkomendasikan untuk dijadikan acuan dalam pengukuran kesiapan pengeloaan aduan E-lapor DIY. Model $e$ readiness yang dikembangkan oleh Mutula dan Brakel mempunyai 6 (enam) variabel, lebih tinggi dibandingkan dengan model $e$-readiness lainnya. Variabel yang terdapat pada model e-readiness Mutula dan Brakel antara lain dengan variabel SOP, organisasi, SDM, TIK, manajemen data (informasi) dan kebijakan. Kelebihan dari e-readiness Mutula dan Brekel telah disediakan tool atau segmen yang telah dilengkapi dengan daftar komponen penilaian yang sudah tervalidasi dan teruji realibilitasnya.

\section{SARAN}

Penelitian selanjutnya diharapkan dapat merancang sebuah model penilaian e-readiness yang disesuaikan khusus menilai kesiapan implementasi teknologi informasi pada sistem pengelolaan pengaduan di Indonesia. Model penilaian e-readiness yang telah disesuaikan dan ditambahkan sesuai dengan kebutuhannya, variabel yang dilibatkan dalam pengembangan model e-readiness mengakomodir seluruh aspek yang berhubungan dengan sistem pengelolaan pengaduan, sehingga hasilnya lebih valid dan dapat dipercaya. Dengan adanya penilaian $e$ readiness yang valid, kepercayaan masyarakat atas pelayanan publik yang dilakukan penyelenggara pelayanan publik dalam hal ini pemerintah meningkat, sehingga menjawab harapan dan tuntutan seluruh warga negara dan penduduk tentang peningkatan pelayanan publik.

\section{DAFTAR PUSTAKA}

[1] Warenpan, N. J., Hadi, S. P., Winarno, W. W., 2018, Peran Strategis Chief Information Officer dalam Mendukung Keterbukaan Informasi Publik di Badan Publik Pemerintah, Semnasteknomedia 2018, Yogyakarta, 02 Februari

[2] Mohanty, P. K., 2005, Using e-Tools for Good Governance \& Administrative Reforms, https://www.cgg.gov.in/core/uploads//2017/07/eGovPaperARC.pdf.

[3] Putro, S., Kusrini., Kurniawan, M. P., 2019, Penerapan Metode UEQ dan Cooperative Evaluation untuk Mengevaluasi User Experience Lapor Bantul, Jurnal CITEC, No. 1, Vol. 6, doi: 10.24076/citec.2019v6i1.242. 
[4] Nento, F., Nugroho, L. E., Selo, 2017, Model E-Readiness Untuk Pengukuran Kesiapan Pemerintah Daerah Dalam Penerapan Smart Government: Studi Kasus Pemerintah Provinsi Gorontalo, Seminar Nasional Inovasi Dan Aplikasi Teknologi Di Industri 2017, Malang, 4 Februari

[5] Bappenas, 2010, Manajemen Pengaduan Masyarakat dalam Pelayanan Publik, Laporan Kajian Manajemen Pengaduan Masyarakat Dalam Pelayanan Publik, Hal. 1-174

[6] Pemerintah Indonesia, 2009, UU Nomor 25 Tahun 2009 Tentang Pelayanan Publik, Lembaran Negara RI Tahun 2008, No. 25, Sekretariat Negara, Jakarta.

[7] Presiden Indonesia, 2013, Peraturan Presiden Nomor 76 Tahun 2013 Tentang Pengelolaan Pengaduan Pelayanan Publik, Sekretariat Negara, Jakarta.

[8] Saefullah, H. A., Djaja., 2008, Pemikiran Kontemporer Administrasi Publik Perspektif Manajemen Sumber Daya Manusia dalam Era Desentralisasi, AIPI dan PK2W Lemlit Univ Padjadjaran, Bandung.

[9] Diskominfo DIY, 2018, Standar Operasional Prosedur E-Lapor DIY, Yogyakarta

[10] Chipembele, M., Bwalya, K. J., 2016, Assesing E-Readiness of the Copperbelt University, Zambia: Case Study, IInternational Journal of Information and Learning Technology, No. 5, Vol. 33.

[11] Yusrizal, 2014, Kesiapan Instansi Dalam Pembentukan Unit Pelayanan Infromasi di Pemerintah Kabupaten Asahan, No. 1, Vol. 15, Hal. 73-88.

[12] Bridges.org, E-Ready for What? E-Readiness in Developing Countries: Current Status and Prospects toward the Millennium Development Goals, https://www.infodev.org/infodevfiles/resource/InfodevDocuments_3.pdf

[13] Beig, L., Montazer, G. A., Ghavamifar, A., 2007, Adoption A Proper Tool For E-Readiness Assessment in Developing Countries (Case Studies: Iran, Turkey and Malaysia), Journal of Knowlege Economy \& Knowlegde Management, vol. II, Hal. 54 - 69

[14] Mutula, S. M., Brakel, P. V, 2006, An evaluation of e-readiness assessment tools with respect to information access: Towards an integrated information rich tool, International Journal of Information Management, No. 3, Vol. 26, Hal. 212-223. doi: 10.1016/j.jinfomgt.2006.02.004.

[15] Rahmah, R., Winarno, W. W., Santosa, I., 2015, Kesiapan Infrastruktur TIK dan Sumber daya Manusia Dalam Penerapan Blueprint E-Governmen, Studi Kasus: Pemerintah Kota Balikpapan, Thesis, Fakultas Teknik, Universitas Gajah Mada, Yogyakarta. 